\title{
Interactive Reading to Second Language Reading Ability
}

\author{
Phirunkhana Phichiensathien* \\ School of Liberal Arts \\ Mae Fah Luang University \\ Chiang Rai, Thailand \\ *phirunkhana.phi@mfu.ac.th
}

\begin{abstract}
The present study extends this line of research by implementing the use of an interactive reading process in the $21^{\text {st }}$ reading classroom. 56 English major students studying in the English Reading and Writing course in the second semester of the academic year 2019 were asked to participate in a voluntary program. Two samples of narrative, expository, and argumentative essays were selected based on these criteria: students' literacy experiences from English Reading and Writing courses and the readability and notion of text types. Pubhtml5 was employed to give the samples of the narrative, expository, and argumentative essays to $\mathrm{L} 2$ learners. A set of questions based on Kolker's affective, cognitive, and linguistic behaviors of reading interactive factors were displayed on padlet to investigate the students' interactions when they read the essays. 20-multiplechoice items were used as a pre-test and post-test, which was designed, based on Barrett's taxonomy of reading comprehension. Paradoxically, L2 students have been challenged to comprehend English passages by translation, which is at odds with the process of raising and replying questions to comprehend the passage. The findings reveal that the higher the scores on the pre-test and post-test, the more significant the learners' reading ability becomes. Subsequently, the findings shed light on how L2 learners, interacting with teachers through padlet, can comprehend English passages. It can be concluded that the process of interactive reading helps improve $L 2$ learners' reading ability.
\end{abstract}

Keywords-interactive reading, padlet, reading ability, raising and replying questions

\section{INTRODUCTION}

The trends of $21^{\text {st }}$-century learning have been greatly concerned with classroom interactivity. Technology plays a significant role in pedagogy in various contexts, particularly in literacy courses. In the academic arena, reading is anticipated as one of the vital skills encouraging learners to gain more knowledge. As Coady suggests, if one can read many English passages, one can comprehend texts more effectively [1]. However, almost all Thai EFL learners have been confronted by several challenges between primary school to higher tertiary level institutions. Because of insufficient of L2 acquisition, they have struggled with English literacy over decades, particularly with the requirements for academically lexical choices, reading comprehension, and critical and analytical skills. Some researchers claim that the differences between L1 and L2 acquisition limit L2 reading comprehension [2]. Subsequently, it has become even more challenging to tackle this problem in the $21^{\text {st }}$ century English classroom.

Most Thai EFL university learners are likely to be passive recipients while studying on reading courses. They wait for the teacher's knowledge and clarification without making any responses. In contrast with active learning and teaching in the class, the learners make use of an online dictionary to translate unfamiliar words. Furthermore, using reading strategies (e.g., skimming, scanning, and guessing meaning from context clues) might not contribute enough to enable them to comprehend the reading passages [3]. Finally, and most importantly, the learners lack understanding and practice in critical and analytical skills.

To become more interactive, a study exposed that using an interactive model in reading comprehension class could help develop learners' reading ability, reading strategy, and reading knowledge [4]. Consequently, it is widely recognized that focusing on interactive reading with a free-online interactive platform can stimulate learners to read and interact with the teacher and their peers. This action research aimed at enhancing students' English reading ability by means of IR process intervention. To achieve this goal, this study taught reading skills in a $21^{\text {st }}$-century context by means of padlet and pubhtml5 online interactive applications to stimulate interactivity between teacher-student and student-student in a reading course and improve learners' reading ability.

\section{LITERATURE REVIEW}

\section{A. Notion of Reading}

It is recognized that reading is a significant skill in many areas. Traditionally, it involves a process of decoding from symbol to verbal communication or spoken to written format [5]. Reading is a receptive skill, which the reader uses to integrate linguistic knowledge and world background knowledge [6]. Concerning the reader's own experiences, 
reading strategies, and this knowledge, the reader will be able to fully comprehend the text [7].

Besides, reading can refer to solitary interactivity, in which the reader can manipulate reading passages [8]. That is, the reader will assimilate his/her preconceptions, apply reading strategies on an interesting topic, and understand the communicative purpose in each genre during the reading process. Ultimately, reading is an interactive process between the reader and the text along with a requirement of lexis and language features, integration of reading strategies, and background knowledge of the reading text (or a dynamic process from language to context).

\section{B. Reading Comprehension}

Initially, a behavioral and cognitive concept from reading comprehension (RC) was transformed into an interactive model for many decades. As pinpointed by Miller, $\mathrm{RC}$ refers to a capability of comprehension and gained knowledge from written texts [9]. Reading strategies, such as identifying the reading purpose, using bottom-up decoding and silent reading, analyzing lexical word, and manipulating discourse markers to suit the context [10], can be applied by teachers in reading classes.

Regarding the complexity of $\mathrm{RC}$, it can be a derivation and construct of denotation from the reading text through interactivity [11]. To correspond with the meaning of the text, the reader should be able to bring their knowledge, interpretative skills, and personal experience to the reading text [12]. Similar to Hedgcock and Ferris, a dynamic stage of RC needs the readers to develop their cognition, and the reading tasks should extend their world knowledge [13]. Accordingly, $\mathrm{RC}$ is a process that interacts with the text and requires the reader to apply their knowledge perceptively [14].

Thus, RC involves the ability to read, interpret, infer, and evaluate texts in contexts beyond the meaning at sentence level. RC requires reading proficiency to identify word recognition effectively [15-17]. Each student might have differences in reading ability because of their RC [17]. Similarly, English comprehension can refer to the performance of students' reading skills, which consists of the ability to identify the meaning of a word in a sentence, the sentence in a paragraph, and the paragraph in an entire text.

In short, $\mathrm{RC}$ is a multidimensional ability, which requires reciprocation between reader and text. Overall, the level of comprehension will be based on the reader's ability to identify lexical meaning, structure, and context or world knowledge from the sentence level to a discourse macrostructure. The reader can decode the original meaning of the text and assimilate it into new knowledge.

\section{Interactive Reading}

Regarding interactive reading (IR), this approach becomes an effective intervention for teaching reading courses by means of three methods: the bottom-up approach, the top-down approach, and reader and text interaction [18]. More importantly, these IR approaches can be integrated with background knowledge or schema [19].

The bottom-up approach (or local strategy) was inspired by behaviorism in the 1950s [20]. This approach includes word recognition, letter identification, semantic knowledge, syntactic structure, and generic units of a textual structure in reading courses $[21,22]$. It can be argued that the top-down approach (sometimes called general strategies [23] or global strategies [24]) enables the reader to comprehend the text through their cognitive skills.

In terms of reader and text interaction, there are three significant factors: affective, cognitive, and linguistic behaviors [25]. These aspects involve the following suppositions:

- The way readers feel about themselves and their situation encourages reading achievement (feelings and emotions);

- The conception of the reading text (reading comprehension); and

- The interaction between readers and writers through textual conventions (language used).

Subsequently, the interaction between the reader and the reading text is a process in which the reader can manipulate textual knowledge and cognitive skill. In other words, it is an active learning process of which the basic approach is to engage the reader in understanding the text. The connection between bottom-up and top-down interactions forms a part of the reader's cognition processes [26]. This requires demanding learning activities, which the reader must apply from the lower levels of literal comprehensive reading (microstructure) to higher levels of applied reading comprehension (macrostructure).

Based on questions [25], it is possible to encourage students to become active learners while reading a text. This study focuses on the interactive process between teacher-student, student-student, and the students with the reading text in a reading course. Using questioning and answer approach in which the three factors, namely, affective, cognitive, and linguistic behaviors is employed.

\section{Teaching Reading in the $21^{\text {st }}$ Century}

The paradigm shift in ELT has been aligned with technology-based instruction in a new sustainable learning environment. Online reading resources have offered a wide range of information, which is easily accessible to students, as a result of which [26,27], English teaching and learning methods have transformed students' acts of learning and reading behavior. However, these three approaches to RC have been significantly integrated with reading strategies over the decades. As recommended in Brown [10], some strategies are implemented in three stages as follows: 
In pre-reading, the students can identify the text with the use of prediction, audiovisual cues, figures, and leading questions to compare the students' background and culture. Whilst reading, students are obliged to comprehend the content of the text by identifying the main idea, the supporting details, the language features, and inferences and decoding the information in figures. In post-reading, students are required to examine their comprehension and language features, recall their understanding of new words and jargon, apply reading strategies, and use the written conventions or discuss their insights into their reading comprehension.

Similarly, teachers could use the reading strategies effectively to develop the three reading stages (pre-reading, while reading, and post-reading) [28]. To begin with prereading, the reading strategies e.g., scanning, skimming, and guessing the content from reading the title can focus readers' understanding of the reading text [29]. According to the question-answer approach during reading, students can ask themselves about their identification of the gist, the major and minor ideas, and the conclusion by monitoring their reading and by trying to understand what they are reading by rereading, clarifying, and summarizing to solve their reading difficulties [30]. Together with evaluation and regulation during or after reading, students can assess their reading performance and recognize their failures in reading comprehension with such strategies [31]. Asking questions can encourage students to observe and evaluate their performance and show how they have gained reading knowledge.

The movement of teaching reading to English language students has been transformed into digital platforms, smartphones, and tablets, which now takes into account teaching reading comprehension through access to unlimited online textual resources. The use of online reading strategies and global strategies could contribute to and challenge students to gain more knowledge and better understanding [32]. As with online reading, it is obligatory to drill the reading process with these reading strategies e.g., reading to raise valuable questions, identifying information, evaluating critically, synthesizing, and writing to communicate [33].

Most importantly, questions have been raised about the most effective way to teach English reading and enhance L2 students' reading ability. Pedagogies need to consider and apply the notion of reading strategies in the digital age practically and effectively. Accordingly, this study introduced the criteria to emphasize a process of IR to enhance students' language and cognitive ability in terms of their English reading ability.

\section{Methodology}

This study was conducted at Mae Fah Luang University, Chiang Rai, Thailand. 56 English major students studying in the English Reading and Writing course in the second semester of the academic year 2019 were asked to participate in a voluntary program. The study followed the ethical procedures of the university and obtained ethics approval from the Mae
Fah Luang University Ethics Committee on Human Research. In addition, the students were asked to sign the informed consent form to participate in this study.

\section{A. Research Instruments}

Two samples of narrative, expository, and argumentative essays were selected based on these criteria: students' literacy experiences from English Reading and Writing courses and the readability and notion of text types. That is, the narrative is at levels 5 (easy to read) and 10 (standard or average to read), the expository is at levels 9-10 (standard or average to read), and argumentative is at levels 10-12 (fairy difficult to read /too difficult to read).

Pubhtml5 is an online interactive platform used to enable students to access the six essay samples provided outside the classroom from weeks 6-8. Each sample was uploaded weekly on pubhtml5 bookshelf in weeks 6,7 , and 8 respectively. Then, the students were required to read the essay in the classroom.

After validation by three experts in English Language Teaching, the set of IR questions on padlet application were used in the classroom to investigate the students' interactions when they read the essays. After the students had read the essay, the researcher would ask the students questions on the text and monitor their answers, and the researcher asked for peer feedback and their reactions to each question. This process lasted 20 minutes. The questions were based on Kolker's IR factors.

20-multiple-choice items were used as a pre-test and posttest, which was designed, based on Barrett's taxonomy of reading comprehension. Three texts were selected based on the aforementioned criteria. In order to promote students' critical and analytical skills for the $21^{\text {st }}$ century, the researcher had designed questions, multiple choices, and purposes at lower to higher cognitive thinking levels: literal comprehension (4 recall items), reorganization (1 item), inferential comprehension (10 items), and evaluation (5 items). The tests were distributed to the students in week 5 before the implementation as a pre-test and in week 8 after the implementation as a post-test. The tests lasted for 45 minutes.

In order to ensure its validity, three experts evaluated the test. They rated each item on its degree of congruence in terms of the Item Objective Congruence Index (IOC) [34]. The evaluation of the test ranged from 1 (Congruent), 0 (Questionable), -1 (Incongruent). The average scores for each item were measured. Scores of between 0.51-1 were acceptable but scores of $0.00-0.50$ scores were modified. The researcher revised the test based on the experts' suggestions, which required many corrections of language features and cognitive thinking levels in terms of the item objectives for content. After the experts' validation, a set of 20 multiplechoice questions on reading comprehension were piloted in November 2018 at the university to 5 English major students who were studying on the English Reading and Writing Course I 


\section{B. Data Analysis}

The results of the tests were quantitatively analyzed by using basic statistics: mean and standard deviation and the Statistical Package for the Social Sciences (SPSS) with a onesample t-test to determine the students' English language reading ability. The mean scores of the pre-test and post-test were compared to examine the development of students' reading comprehension after implementing the use of the interactive reading course for English major undergraduate students.

\section{RESULTS AND DISCUSSION}

In line with the research objectives, the results of the pretest and post-test provided important information on students' reading abilities with regard to the IR process (See Table 1 below).

TABLE I. The Results of the Pre-Test And Post-Test

\begin{tabular}{|c|c|c|c|c|c|c|c|c|c|}
\hline & $\mathbf{n}$ & Mean & SD & Min & Max & $\begin{array}{c}\text { Mean } \\
\text { difference }\end{array}$ & df & $\mathbf{t}$ & Sig \\
\hline $\begin{array}{c}\text { Pre- } \\
\text { test }\end{array}$ & 56 & 11.66 & 1.94 & 8 & 16 & \multirow[t]{2}{*}{2.12} & \multirow[t]{2}{*}{55} & \multirow[t]{2}{*}{9.69} & \multirow[t]{2}{*}{$0.00 *$} \\
\hline $\begin{array}{c}\text { Post- } \\
\text { test }\end{array}$ & 56 & 13.79 & 2 & 9 & 18 & & & & \\
\hline
\end{tabular}

As Table 1 shows, there was a significant difference $(\mathrm{t}=$ $9.69, \mathrm{p}<0.05)$ between the results of the pre-test and post-test using a paired sample t-test. That is, the post-test scores were significantly higher than the results of the pre-test scores $(\mathrm{M}=$ 11.66, 13.79; $\mathrm{SD}=1.94,2$ ).

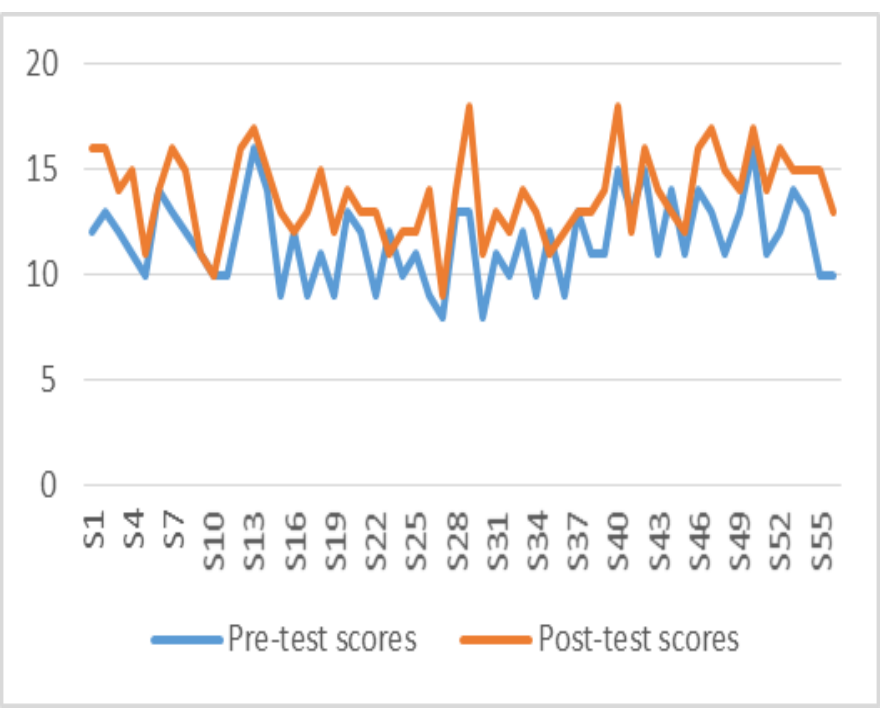

Fig. 1. The results of pre-test and post-test.

As can be seen in Figure 1, the data set of the tests reveals the students' reading development. There is a tendency for the scores to be parallel.
TABLE II. The Results of Individual PRE-Test AND Post-Test SCORES

\begin{tabular}{|c|c|c|c|}
\hline Students & $\begin{array}{c}\text { Pre-test } \\
\text { scores }\end{array}$ & $\begin{array}{l}\text { Post-test } \\
\text { scores }\end{array}$ & $\begin{array}{c}\text { Interpretation } \\
\text { (frequency/percent) }\end{array}$ \\
\hline S1 & 12 & 16 & + \\
\hline $\mathrm{S} 2$ & 13 & 16 & + \\
\hline S3 & 12 & 14 & + \\
\hline S4 & 11 & 15 & + \\
\hline S5 & 10 & 11 & + \\
\hline S6 & 14 & 14 & $=$ \\
\hline S7 & 13 & 16 & + \\
\hline S8 & 12 & 15 & + \\
\hline 59 & 11 & 11 & $=$ \\
\hline S10 & 10 & 10 & $=$ \\
\hline S11 & 10 & 13 & + \\
\hline S12 & 13 & 16 & + \\
\hline S13 & 16 & 17 & + \\
\hline S14 & 14 & 15 & + \\
\hline S15 & 9 & 13 & + \\
\hline S16 & 12 & 12 & $=$ \\
\hline S17 & 9 & 13 & + \\
\hline S18 & 11 & 15 & + \\
\hline S19 & 9 & 12 & + \\
\hline S20 & 13 & 14 & + \\
\hline S21 & 12 & 13 & + \\
\hline S22 & 9 & 13 & + \\
\hline$S 23$ & 12 & 11 & - \\
\hline S24 & 10 & 12 & + \\
\hline S25 & 11 & 12 & + \\
\hline S26 & 9 & 14 & + \\
\hline S27 & 8 & 9 & + \\
\hline S28 & 13 & 14 & + \\
\hline S29 & 13 & 18 & + \\
\hline S30 & 8 & 11 & + \\
\hline S31 & 11 & 13 & + \\
\hline S32 & 10 & 12 & + \\
\hline S33 & 12 & 14 & + \\
\hline S34 & 9 & 13 & + \\
\hline S35 & 12 & 11 & - \\
\hline S36 & 9 & 12 & + \\
\hline S37 & 13 & 13 & $=$ \\
\hline S38 & 11 & 13 & + \\
\hline S39 & 11 & 14 & + \\
\hline S40 & 15 & 18 & + \\
\hline$S 41$ & 13 & 12 & - \\
\hline S42 & 15 & 16 & + \\
\hline S43 & 11 & 14 & + \\
\hline S44 & 14 & 13 & - \\
\hline S45 & 11 & 12 & + \\
\hline S46 & 14 & 16 & + \\
\hline S47 & 13 & 17 & + \\
\hline S48 & 11 & 15 & + \\
\hline S49 & 13 & 14 & + \\
\hline S50 & 16 & 17 & + \\
\hline S51 & 11 & 14 & + \\
\hline S52 & 12 & 16 & + \\
\hline S53 & 14 & 15 & + \\
\hline S54 & 13 & 15 & + \\
\hline S55 & 10 & 15 & + \\
\hline S56 & 10 & 13 & + \\
\hline \multirow{2}{*}{ Mean } & \multirow{2}{*}{11.66} & \multirow{2}{*}{13.79} & $(+47 ;=5 ;-4)$ \\
\hline & & & $83.93 \% ; 8.93 ; 7.14 \%$ \\
\hline
\end{tabular}


Interestingly, the most striking result to emerge from the data is that most students improved their reading ability after being involved in the IR process. As can be seen in table 2, a positive and negative correlation was found between the test results for 47 of the students and 4 of the students (or $83.93 \%$, $7.14 \%$ ); whereas, five of the students had similar pre-test and post-test scores (or $8.93 \%$ ). This indicates that the IR process enhanced the students' reading ability.

This action research indicates the improvements in students' reading comprehension supported by the previous study [4] which aimed to identify the results of the students' pre-test and post-test scores and monitor their progress by using a set of Kolker [25] interactive questions. Nevertheless, the concept of the IR approach (bottom-up and top-down) in the quasi-experimental study [35] can also promote the students' reading development, self-actualization, and the relationship between reading comprehension and reading habits. In line with the findings based on the quantitative data from the pre-test and post-test and questionnaires, it is believed that developing good reading habits is an important aspect of developing reading performance although the students reading habits are poor.

This is consistent with classroom action research by Nur, and Ahmad, which offers crucial evidence that the implementation of the IR model and its effectiveness resulted in improvements in students' English reading [36]. The research outcomes demonstrate how a practical method can be used to initiate an interaction triangle: students-teacherstudents. Nonetheless, it seems that sometimes students' experiences have no effect, as some students (8.93 percent) never improved their reading progress in a comparison of the pre-test and post-test results. Although these results differ from some published studies in an elementary and university context, they are consistent with those of the IR process implementation.

The findings of the IR process can be related to the diversity of the IR process in raising questions on the online platform. Thus, the IR process can strongly encourage students to interact with the teacher and their peers. Besides, it seems that this approach can also motivate the students, as supported by Van der Wilt, et al., [37]. Regardless of a read-aloud process, it is recognized that the teacher can stimulate elementary students to respond and inspire them to comprehend the texts with the use of appropriate reading strategies [38]. Likewise, a study in Monarisa and Suwarno [39], integrates one approach into the IR approach (a sharedbook) by mapping how students' reading development can improve when general and specific questions are used during the IR processes. As can be seen in a longitudinal study [40], using questions with students for the duration of a literature comprehension course shows the benefits of a process approach. Furthermore, it would be possible to employ interactive book activities for a one-year period of data collection. Though this IR approach was implemented with teachers from many different schools, which contributed to the students' improved reading knowledge, this study provides some external validity for the results of the current study.

As for the use of traditional bottom-up and top-down approaches shown in Cetinkaya et al., [41], there were some negative reactions from students because some students were frightened by the prospect of giving incorrect answers. This process, accordingly, dominates students' responses to the reading knowledge. Nonetheless, it may be problematic to assess all student's reading efficacy, as there is a small possibility that some students' answers were insufficient in the study. As shown, one study [37] tends to be concerned with students' achievement in a reading course. Indeed, no comparison of the test results can determine the students' reading development, but then this study was able to identify students' achievements.

\section{CONCLUSION}

Therefore, asking questions and giving answers on padlet as conducted in this study shows how IR can be implemented as one of the teaching approaches to examine students' reading ability. Accordingly, it has been clearly demonstrated that the intervention of the IR process on an online platform can enhance undergraduate students' reading performance in the $21^{\text {st }}$ reading course.

\section{ACKNOWLEDGMENT}

This study has been financially supported by the Academic Extension and Development Office of Mae Fah Luang University.

\section{REFERENCES}

[1] J. Coady, "Research on ESL/EFL vocabulary acquisition: putting it in context," in T. Huckin, M. Haynes, and J. Coady, Eds. Second Language Reading and Vocabulary Learning, New Jersey: Ablex Publishing Corporation, 1995, pp. 3-23.

[2] A. Ammar, P.M. Lightbown, and N. Spada, "Awareness of L1/L2 differences: Does it matter?," Language Awareness, vol. 19, no. 2, pp. 129-146, 2010.

[3] K. Mokhtari, and C.A. Reichard, "Assessing students' metacognitive awareness of reading strategies," Journal of Education Psychology, vol. 94, no. 2, p. 249, 2002.

[4] A. Hamra, and E. Syatriana, "Developing a model of teaching reading comprehension for EFL students," TEFLIN Journal, vol. 21, no. 1, pp. 27-40, 2015.

[5] W.M. Rivers, Teaching Foreign Language Skills in a Foreign Language Skills. Chicago: University of Chicago Press, 1981.

[6] J. Harmer, The Practice of English Language Teaching. 3rd ed., London: Longman, 2002

[7] S. Pang, Teaching Reading. Chicago: University of Illinois, 2003

[8] D. Nunan, Designing Tasks for the Communicative Classroom. Cambridge: Cambridge University Press, 1989.

[9] D. Miller, Reading with Meaning Teaching Comprehension in the Primary Graders. Portland: Stenhouse, 2008

[10] H.D. Brown, Teaching by Principle: An Interactive Approach to Language Pedagogy, San Fransisco: Longman, 2001

[11] C. Snow, Reading for Understanding: Toward an R\&D Program in Reading Comprehension. Santa Monica: Rand Corporation, 2002. 
[12] K. Maria, Reading Comprehension Instruction, Issues, and Strategies. Parkton, MD: York Press, 1990.

[13] J.S. Hedgcock, and D.R. Ferris, Teaching Readers of English-Students, Text, and Context. London: Routledge, 2009.

[14] J. Shin, V. Dronjic, and B. Park, "The interplay between working memory and background knowledge in L2 reading comprehension," TESOL Quarterly, vol. 53, pp. 320-347, 2019.

[15] N. Aprilia, Improving Reading Comprehension of the Eighth Grade Students at SMPN 6 Yogyakarta through Posse Strategy in the Academic Year of 2014/2015, Doctoral dissertation, Faculty of Language and Arts, State University of Yogyakarta, 2015.

[16] J. Brewster, and G. Ellis, The Primary English Teacher's Guide. Edinburgh Gate: Pearson, 2002.

[17] F. Lubis, S. Rambe, and A.N. Habibi, "The effect of making a match technique on students' reading comprehension at XI grade of MAN 1 Padangsidimpuan," English Education: English Journal for Teaching and Learning, vol. 5, no. 1, pp. 1-15, 2017.

[18] H.D. Brown, Teaching by Principles. White Plains, NY: Pearson Education, 2007.

[19] W. Grabe, "Current developments in second language reading research," TESOL Quarterly, vol. 25, no. 3 pp. 375-406, 1991.

[20] E. Block, "See how they read: Comprehension monitoring of L1 and L2 readers," TESOL Quarterly, vol. 26, no. 2, pp. 319-343, 1992.

[21] J. Anderson, Exploring Second Language Reading: Issues and Strategies, Boston: International Thomson Publishing, 1999.

[22] M. A. Omaggio, Teaching Language in Context. Boston: Heinle and Heinle, 1993

[23] C.K. Cheng, A Descriptive Study of Reading Strategies Used by Chinese ESL Students from Taiwan, ROC, Doctoral dissertation, University of Kansas, Teaching and Leadership, 1998.

[24] R. Sheorey, and K. Mokhtari, "Differences in the metacognitive awareness of reading strategies among native and non-native readers," System, vol. 29, pp. 431-449, 2001.

[25] B. Kolker, "Processing Print," in J. E. Alexander, Ed. Teaching Reading, Boston: Little, Brown and Company, 1979 pp. 4-25.

[26] D. Rumelhart, Toward an Interactive Model of Reading, San Diego, California: Center for Human Information Processing, University of Clifornia, 2018.

[27] J.D. Frechette, Developing Media Literacy in Cyberspace, London: Preager, 2002

[28] M. Warschauer, and T. Matuchniak, "New technology and digital world: Analyzing evidence of equity in access, use, and outcomes," Review of Research in Education, vol. 34, no. 4, pp. 566-580, 2010.

[29] A. Mejang, The development of an English reading strategy instruction model based on collaborative learning principles for enhancing reading learning outcomes of university students, Doctor Dissertation, Chulalongkorn University, Thailand, 2004.

[30] S. Allen, "An analytic comparison of three models of reading strategy instruction," IRAL, 2003, pp. 319-338.

[31] K. Zabrucky, and H.H. Ratner, "Effects of passage type on comprehension monitoring and recall in good and poor readers," Journal of Reading Behavior, vol. 24, pp. 373-391, 1992.

[32] H. Huang, C. Chern, and C. Lin, "EFL learners' use of online reading strategies and comprehension of texts: An exploratory study," Computer \& Education, vol. 52, no. 1, pp. 13-26, 2009.

[33] J. Castek, L. Zawilinski, J.G. McVerry, W.I. O'Byrne, and D.J. Leu, "The new literacies of online reading comprehension: New opportunities and challenges for students with learning difficulties," in Multiple Perspectives on Difficulties in Learning Literacy and Numeracy, Springer, Dordrecht, 2011, pp. 91-110.

[34] R.J. Rovinelli and R.K. Hambleton, "The use of content specialists in the assessment of criterion-referenced test item validity: 1977,” Dutch J Edu Res., 1977.

[35] I. Fitriyah, "Students' reading comprehension: Between the effectiveness of interactive approach, reading habit and selfactualization," in International Conference on English Language Teaching (ICONELT 2019), Atlantis Press, 2020, pp. 37-41.

[36] A.H. Nur, and D. Ahmad, "Improving students' reading skill through interactive approach at the first grade of Sman 1 Mare, Bone,: Eternal (English, Teaching, Learning, and Research Journal), vol. 3, no. 1, pp. 44-56, 2017.

[37] F. van der Wilt, I. Boerma, B. van Oers, and C. van der Veen, "The effect of three interactive reading approaches on language ability: An exploratory study in early childhood education," European Early Childhood Education Research Journal, vol. 27, no. 4, pp. 566-580, 2019.

[38] N. Hayati, U. Kasim, and A. Muslem, "Using interactive approach in enhancing students' reading comprehension," English Education Journal, vol. 11, no. 2, pp. 231-250, 2020.

[39] A. Monarisa, and B. Suwarno, "Teaching reading comprehension through the interactive technique (a quasi-experimental research at The SMPN 1 Bengkuku City)," Linguists: Journal of Linguistics and Language Teaching, vol. 2, no. 1, 2016.

[40] E. Sadeghi, A. Afghari, and G.R. Zarei, "Shadow-reading effect on reading comprehension: actualization of interactive reading comprehension: ( a Vygotskyan view!)," English Language Teaching, vol. 9, no. 3, pp. 130-138, 2016.

[41] F.Ç. Çetinkaya, S. Ates, and K. Yildirim, "Effects of interactive book reading activities on improvement of elementary school students' reading skills," International Journal of Progressive Education, vol. 15, no. 3, pp. 180-193, 2019. 